\title{
Production, extraction and characterization of exopolysaccharides produced by the native Leuconostoc pseudomesenteroides $\mathbf{R} 2$ strain
}

\author{
ELINALVA M. PAUlO ${ }^{1}$, EliSANGELA F. BOFFO ${ }^{4}$ ALEXSANDRO BRANCO $^{2}$, ÂNGELA M.M.P. VALENTE $^{3}$, \\ ITAMAR S. MELO ${ }^{3}$, ANTONIO G. FERREIRA ${ }^{5}$, MILTON R.A. ROQUE ${ }^{6}$ and SANDRA A. DE ASSIS ${ }^{2}$ \\ ${ }^{1}$ Departamento de Ciências Biológicas, Universidade Estadual de Feira de Santana (UEFS), \\ Av. Transnordestina, s/n, Km 0, BR 116, 44036-900 Feira de Santana, BA, Brasil \\ ${ }^{2}$ Departamento de Saúde, Universidade Estadual de Feira de Santana (UEFS), \\ Av. Transnordestina, s/n, Km 0, BR 116, 44036-900 Feira de Santana, BA, Brasil \\ ${ }^{3}$ Laboratório de Microbiologia Ambiental, Embrapa Meio Ambiente (CNPMA), \\ Via SP 340, Km 127,5, Caixa Postal 69, 13820-000 Jaguariúna, SP, Brasil \\ ${ }^{4}$ Departamento de Química Orgânica, Instituto de Química, Universidade Federal da Bahia, \\ Campus Universitário de Ondina, 40170-115 Salvador, BA, Brasil \\ ${ }^{5}$ Laboratório de Ressonância Magnética Nuclear, Departamento de Química, \\ Universidade Federal de São Carlos, Rodovia Washington Luiz, \\ Km 235, Caixa Postal 676, 13565-905 São Carlos, SP, Brasil \\ ${ }^{6}$ Instituto de Ciências da Saúde, Universidade Federal da Bahia (UFBA), \\ Campus Universitário de Ondina, 40170-115 Salvador, BA, Brasil
}

Manuscript received on May 9, 2011; accepted for publication on August 3, 2011

\begin{abstract}
The genus Leuconostoc belongs to a group of lactic acid bacteria usually isolated from fermented vegetables, which includes species involved in the production of exopolysaccharides (EPS). These biopolymers possess considerable commercial potential. Because of the wide variety of industrial applications of EPS, this study aimed to produce and characterize the native exopolysaccharide strain Leuconostoc pseudomesenteroides $\mathrm{R} 2$, which was isolated from cabbage collected in a semi-arid region of Bahia. We employed the following conditions for the production of EPS: $10.7 \%$ sucrose, $\mathrm{pH} 8.2$, without agitation and incubation at $28^{\circ} \mathrm{C}$ for 30 hours. The fermentation broth was treated with ethanol and generated two types of polysaccharide substances (EPS I and EPS II). The identification of EPS I and EPS II was conducted using FT-IR, ${ }^{1} \mathrm{H},{ }^{13} \mathrm{C}$ and DEPT-135 NMR spectra. The two substances were identified as linear dextran $\alpha$ polysaccharides $(1 \rightarrow$ 6) which indicated different characteristics with respect to thermal analysis and density of free packaging, viscosity and time of solubilization. Both dextrans are of low density, possess high thermal stability and exhibited the behavior characteristic of pseudoplastic polymers.
\end{abstract}

Key words: Leuconostoc pseudomesenteroides, exopolysaccharide, polymer, dextran.

\section{INTRODUCTION}

Microbial polysaccharides possess rheological properties that are conducive to industrial applications and can be produced in large quantities and at high

Correspondence to: Sandra Aparecida de Assis

E-mail: sandraassis@uefs.br levels of purity. The interest of the food industry in developing multifunctional additives that not only provide the desired improvement of food texture but also have additional nutritional properties led to an extensive search for polysaccharides with prebiotic attributes (Korakli et al. 2003). 
The exopolysaccharides (EPSs) are composed of secondary metabolites produced when some microorganisms are not in conditions favorable to their proliferation (Mesomo et al. 2009). EPSs consist of monosaccharides and may include noncarbohydrate constituents, such as acetate, pyruvate, succinate and phosphate (Pace 1992). Because EPSs form long linear or circular chains, they exhibit high molecular weight (Laws et al. 2001).

EPSs are produced intracellularly and extracellularly. Research investigating industrial applications is concentrated on the extracellular polysaccharides, which have simpler extraction and purification processes and can be produced in greater quantities (Sutherland 2002).

Most lactic acid bacteria are harmless to human health, and under optimal conditions, many species are capable of producing EPSs in large quantities, providing a suitable option in the use of this polymer in products intended for human consumption (Ricciardi and Clementi 2000, Laws et al. 2001). Various steps are employed to obtain the EPSs produced in microbial cultures that involve a combination of extraction, purification and quantification techniques (Galindo 1994).

The identification and characterization of polymers requires physical-chemical, mechanical and thermal stresses. Polymers can also be identified by rheological techniques and immunological assays (Rohm Haas Company 2002). Generally, three to five of these techniques are employed in combination for the characterization of polymers (Lucas et al. 2001, Silva et al. 2003).

There is a strong incentive to exploit microbial polysaccharides commercially, as they possess specific properties of considerable biotechnological interest, with possible applications in foods as thickening and gelling agents and in clinical trials as plasma thickening agents (Bohn and Bemiller 1995, Berovič et al. 2003). However, the biological activity of EPS is related to physical-chemical properties (Leung et al. 2006, Young and Jacobs 1998).
Due to the wide application of biopolymers, this study aimed to produce native exopolysaccharides strains of Leuconostoc pseudomesenteroides R2, identify and characterized them for industrial applications.

\section{MATERIALS AND METHODS}

MATERIALS

Sucrose and trichloroacetic acid were purchased from Sigma (Sigma Chemical Co., St Louis, MO, USA). All other chemicals used were of highquality analytical grade.

\section{PRODUCTION OF EXOPOLYSACCHARIDES BY}

MiCROORGANISMS

We used a bacterial strain isolated from cabbage collected in the semi-arid region of Bahia that we identified by a molecular method (16S rRNA) as Leuconostoc pseudomesenteroides. This strain does not present the virulence factors hemolysin and gelatinase, which are present in the pathogenic Gram-positive coco bacteria.

\section{PRODUCTION OF EXOPOLYSACCHARIDES}

For inocula, aliquots of $1 \%$ of the active culture of the L. pseudomesenteroides $\mathrm{R} 2$ strain, which is proliferative in MRS broth, were employed, with an absorbance of $1.92 \pm 0.01$ at $600 \mathrm{~nm}$ that corresponds with approximately $4.0 \times 10^{8} \mathrm{CFU} / \mathrm{mL}$ of bacteria.

For culture conditions, we employed the conditions previously optimized for the production of EPSs by the L. pseudomesenteroides R2 strain: $10.7 \%$ sucrose, $\mathrm{pH} 8.2$, without aeration, and incubation at $28^{\circ} \mathrm{C}$ for $30 \mathrm{~h}$ (Guimarães et al. 1999).

For the extraction of exopolysaccharides, after the incubation period, the culture was treated with $10 \%$ trichloroacetic acid (1:1), homogenized for $30 \mathrm{~min}$ in the incubator shaker (Marconi MA420) at $90 \mathrm{rpm}$ and $25 \pm 2{ }^{\circ} \mathrm{C}$ and then centrifuged at 
$8150 \mathrm{~g}$ for $20 \mathrm{~min}$ (refrigerated centrifuge Sorvalo, GS-3 rotor). The pelleted material was discarded, and absolute alcohol (1:2) was added to the supernatant, which was stored in the refrigerator $\left(4^{\circ} \mathrm{C}\right)$ for 24 hours (Cerning 1995). The EPS precipitates were separated using decantation flasks. Each precipitate was partially purified by conducting three successive washes in distilled water, followed by reprecipitation in absolute alcohol (Pace 1992). Subsequently, the precipitates underwent dialysis in distilled water (300 times the volume of the sample) by adding in membranes with an exclusion limit of $15 \mathrm{kDa}$ (Ashtaputre and Shah 1995, Diltz and Zeller 2001, Chi and Zhao 2003). The EPS precipitates were dried in an oven at $40 \pm 2^{\circ} \mathrm{C}$ to a constant weight after being crushed in a Splabor analytical model Q298A21 mill. The EPSs in the form of powder were stored in airtight glass jars at $4^{\circ} \mathrm{C}$ until the time of analysis.

The EPSs were quantified using procedures of Ruijssenaars et al. (2000), which were employed concomitantly to determine the total sugar by the phenol sulfuric method (Dubois et al. 1956) and reducing sugar (RS) by the dinitrosalicylic acid method (DNS) described by Miller (1959). For these tests, $0.001 \mathrm{~g}$ of each type of precipitate (EPS I and EPS II) was dissolved in $100 \mathrm{~mL}$ of water.

The EPS levels in the concentrates were determined by subtracting the concentration of total sugar by the concentration of reducing sugar $(\mathrm{EPS}=\mathrm{AT}-\mathrm{AR})$.

\section{STRUCTURAL IDENTIFICATION OF EXOPOLYSACCHARIDES}

Scanning Electron Microscope (SEM): The samples dried in powder form (dried at $40{ }^{\circ} \mathrm{C}$ to constant weight) were observed under a "field emission" scanning Gemini Leo - 982 Zeiss Leica microscope at the Environmental Microbiology Laboratory of Embrapa Environment.

For NMR data acquisition and processing, all spectra were recorded at $298 \mathrm{~K}$ on a Varian UNITYplus spectrometer operating at $9.4 \mathrm{~T}$, obser- ving ${ }^{1} \mathrm{H}$ at 400.1 and ${ }^{13} \mathrm{C}$ at 100.6 and using a direct probe method. The samples were dissolved in $\mathrm{D}_{2} \mathrm{O}$ and transferred to NMR tubes. A solution of sodium-3-trimethylsilyl-propionate (TMSP2,2,3,3-d4) prepared in $\mathrm{D}_{2} \mathrm{O}$ was employed as a chemical shift reference (d 0.0). $\mathrm{D}_{2} \mathrm{O}(99.9 \%)$ and TMSP (98\%) were from Cambridge Isotope Laboratories, Inc. (USA).

All experiments were performed in the Department of Chemistry (DQ) - Laboratory of Nuclear Resonance Magnetic - Federal University of São Carlos (UFSCar).

For FT-IR spectrometry, the analysis was processed on a Spectrum One - FIT - IR Spectrometer - Perkin Elmer. The spectra were obtained in the form of a potassium bromide tablet $(\mathrm{KBr})$ in 4000 to $450 \mathrm{~cm}^{-1}$.

For thermogravimetric analysis (TGA), performed at the Institute of Chemistry at Federal University of Bahia, a thermo balance TGA-50 (Shimadzu) was employed, with pots of $\mathrm{Pt}, \mathrm{N}_{2}$ flow $50 \mathrm{~mL} \mathrm{~min}{ }^{-1}$ with a heating rate of $20^{\circ} \mathrm{C}$ $/$ min $20-600^{\circ} \mathrm{C}$ and with masses between 7.0 and $8.0 \mathrm{mg}$. Data were analyzed by applying the method of Freeman-Carroll to obtain the kinetic parameters related to the degradation of polymeric material, which requires the calculation of various derivatives that were obtained graphically with the aid of a computer software.

For apparent viscosity, samples of dried EPSs were dissolved in $10 \mathrm{~mL}$ of distilled water at $1 \%$ and $5 \%(\mathrm{w} / \mathrm{v})$. We used $8 \mathrm{~mL}$ of aqueous preparations of EPSs for determinations of viscosity, which were performed in a Brookfield model DV-III digital rheometer coupled with a water bath stabilized at a temperature of $25^{\circ} \mathrm{C}$ using the SC4-18 adapter stem for small samples. The determination of viscosity was performed in 30 points at 1-minute intervals with a reading duration of 10 seconds and a shear rate ranging 1 to $15.5 \mathrm{~s}^{-1}$, with speeds ranging from 1-12 rpm. The viscosity measurements were performed according to the shear stress and shear 
rate applied to the samples. The readings were interpreted as per millipascal seconds $\left(\mathrm{mPa}^{-\mathrm{s}}\right)$.

For testing the solubilization of EPS, the method used by Astolfi-Filho et al. (2005) was employed with some modifications. One gram of ground polymer (powder) was added to $100 \mathrm{~mL}$ of distilled water. The mixtures were shaken in a shaker (model mark Marconi MA420) at $25{ }^{\circ} \mathrm{C}$ and $150 \mathrm{rpm}$. We measured the time required for the dissolution of each sample to the point at which they were no longer viewed as solids. The absence of lumps was determined with the microscope.

For the density of free packaging, the volume occupied by about $10 \mathrm{~g}$ of crushed EPS (dust) deposited in a 100 graduated cylinder was measured. We lightly struck the cylinder against a flat surface from a height of $2.5 \mathrm{~cm}$ until the volume occupied by the powder reached a constant value, which was applied to calculate the density using the following formula: Dap = mass $(\mathrm{g}) /$ apparent volume $(\mathrm{mL})$ (Astolfi-Filho et al. 2005), where Dap is gross density, which corresponds to the volume occupied by a given mass of a solid (powder or granular) including the air contained in intragrains.

\section{RESULTS AND DISCUSSION}

\section{EXTRACTION AND PURIFICATION}

The process of the extraction of EPSs from the fermented broth of L. pseudomesenteroides R2 after $30 \mathrm{~h}$ of incubation yields EPSs in the form of a viscous and light-colored gel with abundant gas production. In the extraction of EPSs with absolute ethanol, EPS I formed a surface phase and EPS II formed a sediment at the bottom of the beaker. The EPS I phase was crowded, spongy and whitish in color (Figure 1.a), exhibiting greater dry weight (97\%) when compared with the EPS II phase (83\%), which consisted of a viscous liquid and brown color (Figure 1.b). The precise concentration of the dry weight of EPS I was $83.0 \% \pm 9.6$, and that of EPS II was $82.5 \% \pm 4.6$.
Jeanes et al. (1974) classified types of dextran exopolysaccharides produced by 96 bacterial strains, not only by structural and rheological characterizations, but also by physical appearance after the preparation with alcohol.

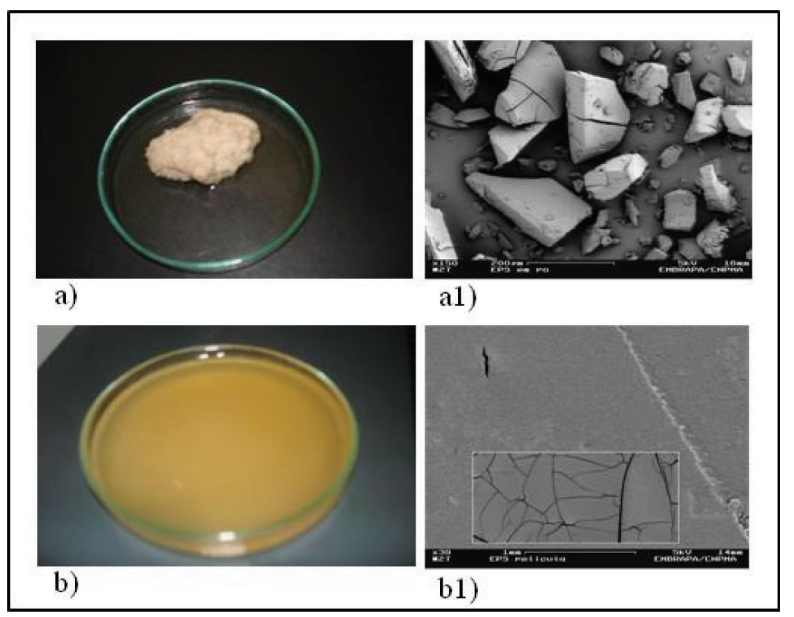

Fig. 1 a) Polymer surface (EPS I) and a1) scanning electron micrographs of EPS I. b) sedimented polymer (EPS II) and b1) scanning electron micrographs of EPS II characteristics of L. pseudomesenteroides R2.

In scanning electron microscopy, EPS I appeared as a compact substance and EPS II presented a brittle film (Figure 1.a1 and Figure 1.b1, respectively). Polymers of high molecular weights form viscous solutions, and evaporating the solvents of these viscous solutions results in the formation of films (Misaki et al. 1980).

The EPS I dried, crushed and dissolved in water at low concentrations assumes the form of a gel that is characteristic of a polymer hydrogel or hydrocolloid. The hydrogels exhibit a strong affinity for water, due to the presence of hydrophilic groups such as $-\mathrm{OH}$, $-\mathrm{COOH},-\mathrm{CONH} 2$ and $\mathrm{SO}_{3} \mathrm{H}$ (Aouada et al. 2008).

IDENTIFICATION OF EXOPOLYSACCHARIDES

The FT-IR spectrum of the exopolysaccharides (EPSs) (Figure 2) produced by the bacterium Leuconostoc pseudomesenteroides $\mathrm{R} 2$ indicated an intense absorption band in the region of $3413 \mathrm{~cm}^{-1}$ on the stretching vibration of hydroxyl groups of links 
$(\mathrm{OH})$, indicating the presence of a polyhydroxilic compound (Liu et al. 2007). The bands in the region of $2920 \mathrm{~cm}^{-1}$ and $1645 \mathrm{~cm}^{-1}$ are due to stretching vibrations of $\mathrm{C}-\mathrm{H}$ bonds, in accordance with $\mathrm{Cao}$ et al. 2006 and Liu et al. 2007.

The main absorption bands that characterize the dextran $\alpha(1 \rightarrow 6)$ exopolysaccharide were found in the region of $1150 \mathrm{~cm}^{-1}$, being related to the vibrations of the link glycoside C-O-C, and of $912 \mathrm{~cm}^{-1}$ and indicating the existence of this glycoside link in the alpha $(\alpha)$ conformation. The presence of an absorption peak at $1010 \mathrm{~cm}^{-1}$ reflects the great flexibility of the chain of dextran described by Shingel (2002).

EPS precipitates were analyzed by ${ }^{1} \mathrm{H}$ and ${ }^{13} \mathrm{C}$ NMR techniques because Nuclear Magnetic Resonance Spectroscopy is the most widely used technique in the elucidation of organic compounds derived from natural products, from organic synthesis or from complex systems such as food (Boffo et al. 2009).
The ${ }^{1} \mathrm{H}$ NMR spectrum of the exopolysaccharide EPS I (Figure 3) showed resonances of hydrogen corresponding to the glucosyl residue, a repeat unit of the biopolymer. Carbonyl hydrogens of D-glucopyranose (H-4) were observed as a triplet $(t)$ in $\delta 3.53 \mathrm{ppm}$, with a constant coupling $(J)$ of $9.4 \mathrm{~Hz}$; H-2 was observed in $\delta 3.58 \mathrm{ppm}$ as a doublet of doublets $(d d)$, with $J$ of 10.0 and 3.4 $\mathrm{Hz}$; $\mathrm{H}-3$ was observed in $3.74 \mathrm{ppm}$ as a doublet of doublets $(d d)$, with $J$ of 10.0 and $9.4 \mathrm{~Hz}$; H-5 was observed in $\delta 3.92 \mathrm{ppm}$ as a broad doublet (brd), with $J$ of $8.8 \mathrm{~Hz}$; and H-6 was observed in $\delta 3.99$ ppm as a broad doublet (brd), with $J$ of $8.5 \mathrm{~Hz}$. Finally, in $\delta 4.99 \mathrm{ppm}$, a doublet $(J=3.20 \mathrm{~Hz})$ was observed, due to anomeric hydrogen $(\mathrm{H}-1)$. The coupling constant observed is characteristic of the alpha conformation $(\alpha)$ from D-glucopyranose.

Seymour (1979) showed that the ${ }^{1} \mathrm{H}$ NMR spectral region for anomeric hydrogen of dextran from L. mesenteroides NRRL B-1355 contained a resonance

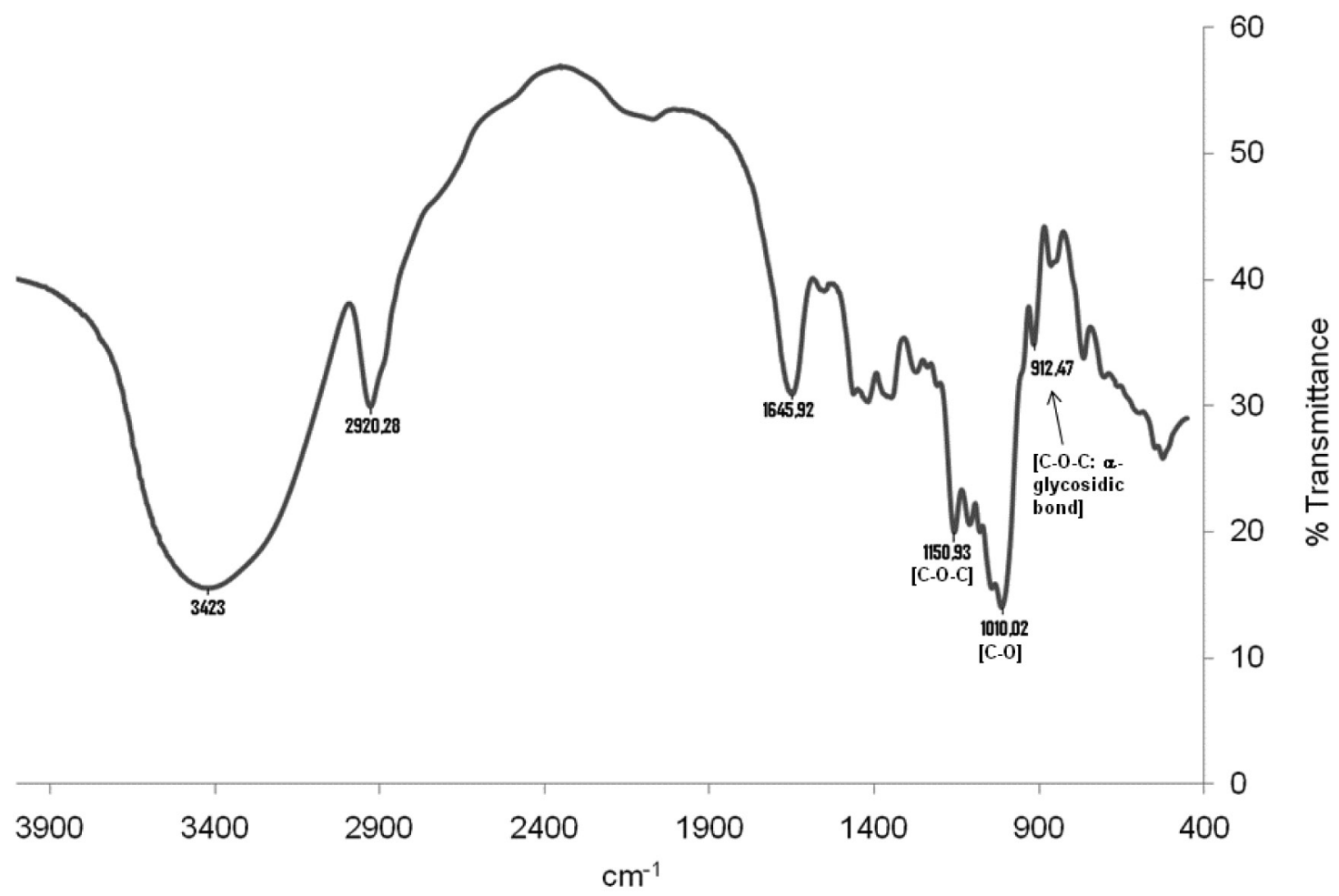

Fig. 2 Infrared spectrum $(\mathrm{KBr})$ of dextran $\alpha(1 \rightarrow 6)($ EPS I) produced by Leuconostoc pseudomesenteroides R2. 


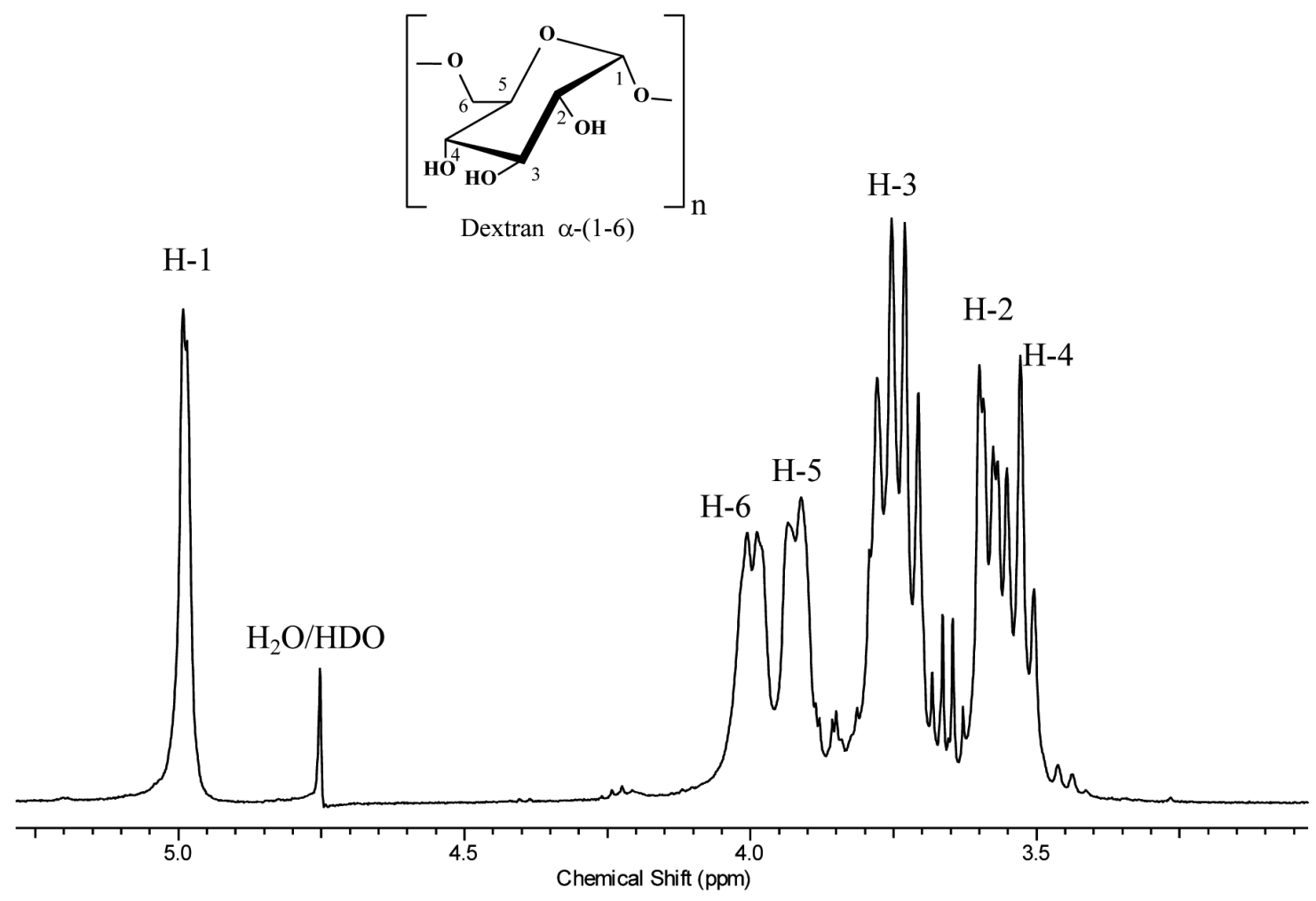

Fig. $3{ }^{1} \mathrm{H}$ NMR spectrum of EPS I produced by Leuconostoc pseudomesenteroides $\mathrm{R} 2\left(400 \mathrm{MHz}\right.$, in $\mathrm{D}_{2} \mathrm{O}$ ).

at $4.95 \mathrm{ppm}$, and the branched linkages contained the resonance peak at $5.3 \mathrm{ppm}$. In the 1H NMR spectrum of EPS showed a resonance at $4.99 \mathrm{ppm}$, confirming that the substance does not have ramifications.

The ${ }^{13} \mathrm{C}$ NMR spectrum of the exopolysaccharide EPS I is shown in Figure 4. C-1 was observed at $\delta$ $100.6 \mathrm{ppm} ; \mathrm{C}-2$ at $\delta 74.3 \mathrm{ppm}$; $\mathrm{C}-3$ at $\delta 76.3 \mathrm{ppm}$; C-4 at $\delta 73.0$ ppm; C-5 at $\delta 72.4$ ppm; C-6 at $\delta 68.4$ ppm. ${ }^{13} \mathrm{C}$ NMR resonances with in the $\delta 70$ to $77 \mathrm{ppm}$ region are associated with free positions at $\mathrm{C}-2, \mathrm{C}-3$ and $\mathrm{C}-4$ residues.

No additional peaks were observed in the region of $\delta 77-85 \mathrm{ppm}$, indicating that the absence of branched linkages and confirming that the dextran synthesized by Leuconostoc pseudomesenteroides $\mathrm{R} 2$ is a highly linear dextran with $\alpha(1 \rightarrow 6)$ glycosidic bonds (Seymour 1979, Uzochukwu et al. 2002).

The chemical shifts of the carbons were confirmed by the analysis of the DEPT-135 spectrum. The spectrum showed five signals of methine carbons $(\mathrm{CH})$ referring to the carbons $\mathrm{C}-1$, C-2, C-3, C-4 and C-5, and a single carbon (C-6) concerning the methylene group $\left(\mathrm{CH}_{2}\right)$.

Using IR, ${ }^{1} \mathrm{H},{ }^{13} \mathrm{C}$ and DEPT-135 NMR data and literature data (Table I), we concluded that the polysaccharide EPS I produced by the bacterium Leuconostoc pseudomesenteroides $\mathrm{R} 2$ corresponds to a linear polymer formed by repetition units of 1-6- $\alpha$-D-glucosyl residual.

In addition to the literature data used to confirm the structure of the EPS I as dextran, we also performed a ${ }^{13} \mathrm{C}$ NMR experiment with D-glucose with the free hydroxyl $(\mathrm{OH})$ group and compared their chemical shifts with the repeating unit glucosyl (C-O-) polymer.

This difference in the values of the chemical shifts of carbons is due to different chemical environments in which they are found in certain compounds. In the molecule of glucose, C-1 and C-6 hydroxy groups are linked to $(\mathrm{OH})$, and 




Fig. $4{ }^{13} \mathrm{C}$ NMR spectrum of EPS I produced by Leuconostoc pseudomesenteroides $\mathrm{R} 2\left(100 \mathrm{MHz}\right.$, in $\left.\mathrm{D}_{2} \mathrm{O}\right)$.

in dextran $\alpha(1 \rightarrow 6)$ they are linked to glucosyl groups $\left(\mathrm{CO}^{-}\right)$or glucosidal $\alpha(1 \rightarrow 6)$. However, for the remaining carbons $(\mathrm{C}-2, \mathrm{C}-3, \mathrm{C}-4$ and $\mathrm{C}-5$ ), chemical shift values are not as distant, as they are in the same chemical environment of both substances (both linked to hydroxyl groups $(\mathrm{O}-\mathrm{H})$.

Data from experiments with ${ }^{1} \mathrm{H},{ }^{13} \mathrm{C}$ and the DEPT-135 NMR spectra, when compared with the literature, leads to the conclusion that I substance polysaccharide (EPS I) produced by the bacterium Leuconostoc pseudomesenteroides $\mathrm{R} 2$ corresponds to a linear polymer composed of repeats of units of residual 6- $\alpha$-D-glucosyl.

The ${ }^{1} \mathrm{H}$ NMR spectrum of the exopolysaccharide EPS II (Figure 5) also showed signals of hydrogens that corresponded to the glucosyl residue. The carbonyl hydrogens of
D-glucopyranose (H-4) were observed as a triplet $(t)$ in $\delta 3.51 \mathrm{ppm}$, with a constant coupling $(J)$ of $9.6 \mathrm{~Hz} ; \mathrm{H}-2$ was observed in $\delta 3.57 \mathrm{ppm}$ as a doublet of doublets $(d d)$, with $J$ of 9.7 and 3.3 $\mathrm{Hz}$; H-3 was observed in $3.72 \mathrm{ppm}$ as a doublet of doublets $(d d)$, with $J$ of 9.8 and $9.3 \mathrm{~Hz}$; H-5 was observed in $\delta 3.90 \mathrm{ppm}$ as a broad doublet (brd), with $J=8.6 \mathrm{~Hz}$; and H-6 was observed in $\delta 3.98$ ppm as a broad doublet (brd), with $J$ of $8.5 \mathrm{~Hz}$. Finally, a doublet was observed in $\delta 4.97 \mathrm{ppmt}$ $(J=3.1 \mathrm{~Hz})$ due to anomeric hydrogen $(\mathrm{H}-1)$.

The ${ }^{13} \mathrm{C}$ NMR spectrum of the exopolysaccharide EPS II is shown in the Figure 6. C-1 was observed at $\delta 100.6 \mathrm{ppm} ; \mathrm{C}-2$ at $\delta 74.3 \mathrm{ppm} ; \mathrm{C}-3$ at $\delta 76.3$ ppm; C-4 at $\delta 73.1 \mathrm{ppm}$; C-5 at $\delta 72.5 \mathrm{ppm}$; $\mathrm{C}-6$ at $\delta 68.5 \mathrm{ppm}$. These results also confirm that EPS II as dextran $\alpha(1 \rightarrow 6)$. 
TABLE I

${ }^{1} \mathrm{H},{ }^{13} \mathrm{C}$, DEPT-135, NMR data for EPS I and EPS II produced by Leuconostoc pseudomesenteroides R2, literature data (SARWAT et al. 2008) and $\alpha$-D-glucopyranose (experimental).

\begin{tabular}{|c|c|c|c|c|c|c|}
\hline \multirow{2}{*}{ Position } & \multicolumn{2}{|c|}{ EPS I } & \multicolumn{2}{|l|}{ EPS II } & \multirow{2}{*}{$\begin{array}{c}\begin{array}{c}\text { Literature } \\
\text { (SARWAT } \\
\text { et al. 2008) }\end{array} \\
{ }^{13} \mathbf{C ~} \boldsymbol{\delta}\end{array}$} & \multirow{2}{*}{$\begin{array}{c}\begin{array}{c}\alpha-\mathrm{D}- \\
\text { glucopyranose } \\
\text { (experimental) }\end{array} \\
{ }^{13} \mathrm{C} \delta\end{array}$} \\
\hline & $\begin{array}{c}{ }^{1} \mathbf{H} \boldsymbol{\delta} \text { (multiplicity; } \\
J \text { in } \mathrm{Hz} \text { ) }\end{array}$ & $\begin{array}{c}{ }^{13} \mathrm{C} / \mathrm{DEPT} \\
135 \delta\end{array}$ & $\begin{array}{c}{ }^{1} \mathbf{H} \boldsymbol{\delta} \text { (multiplicity; } \\
J \text { in Hz) }\end{array}$ & ${ }^{13} \mathrm{C} \delta$ & & \\
\hline 1 & $4.99(d ; 3.2)$ & $100.6(\mathrm{CH})$ & $4.97(d ; 3.1)$ & 100.6 & 100.562 & 93.6 \\
\hline 2 & $3.58(d d ; 10.0 ; 3.4)$ & $74.3(\mathrm{CH})$ & $3.57(d d ; 9.7 ; 3.3)$ & 74.3 & 74.258 & 72.9 \\
\hline 3 & $3.74(d d ; 10.0 ; 9.4)$ & $76.3(\mathrm{CH})$ & $3.72(d d ; 9.8 ; 9.3)$ & 76.3 & 76.253 & 74.3 \\
\hline 4 & $3.53(t ; 9.4)$ & $73.0(\mathrm{CH})$ & $3.51(t ; 9.6)$ & 73.1 & 73.048 & 71.2 \\
\hline 5 & $3.92(\mathrm{brd} ; 8.8)$ & $72.4(\mathrm{CH})$ & $3.90(\mathrm{brd} ; 8.6)$ & 72.5 & 72.435 & 73.0 \\
\hline 6 & $3.99(\mathrm{brd} ; 8.5)$ & $68.4\left(\mathrm{CH}_{2}\right)$ & $3.98(\mathrm{brd} ; 8.5)$ & 68.5 & 68.487 & 62.1 \\
\hline
\end{tabular}

Multiplicity: $d$ - doublet, br $d$ - broad doublet, $d d$ - doublet of doublets, $t$ - triplet.

$\delta$ - Chemical shift (in ppm). ${ }^{1} \mathrm{H}$ and ${ }^{13} \mathrm{C}$ chemical shifts are reported with respect to the $\mathrm{CH}_{3}$ resonance of TMSP- $\mathrm{d}_{4}$.

$J$ - Coupling constant (in $\mathrm{Hz}-\mathrm{Hertz}$ ).

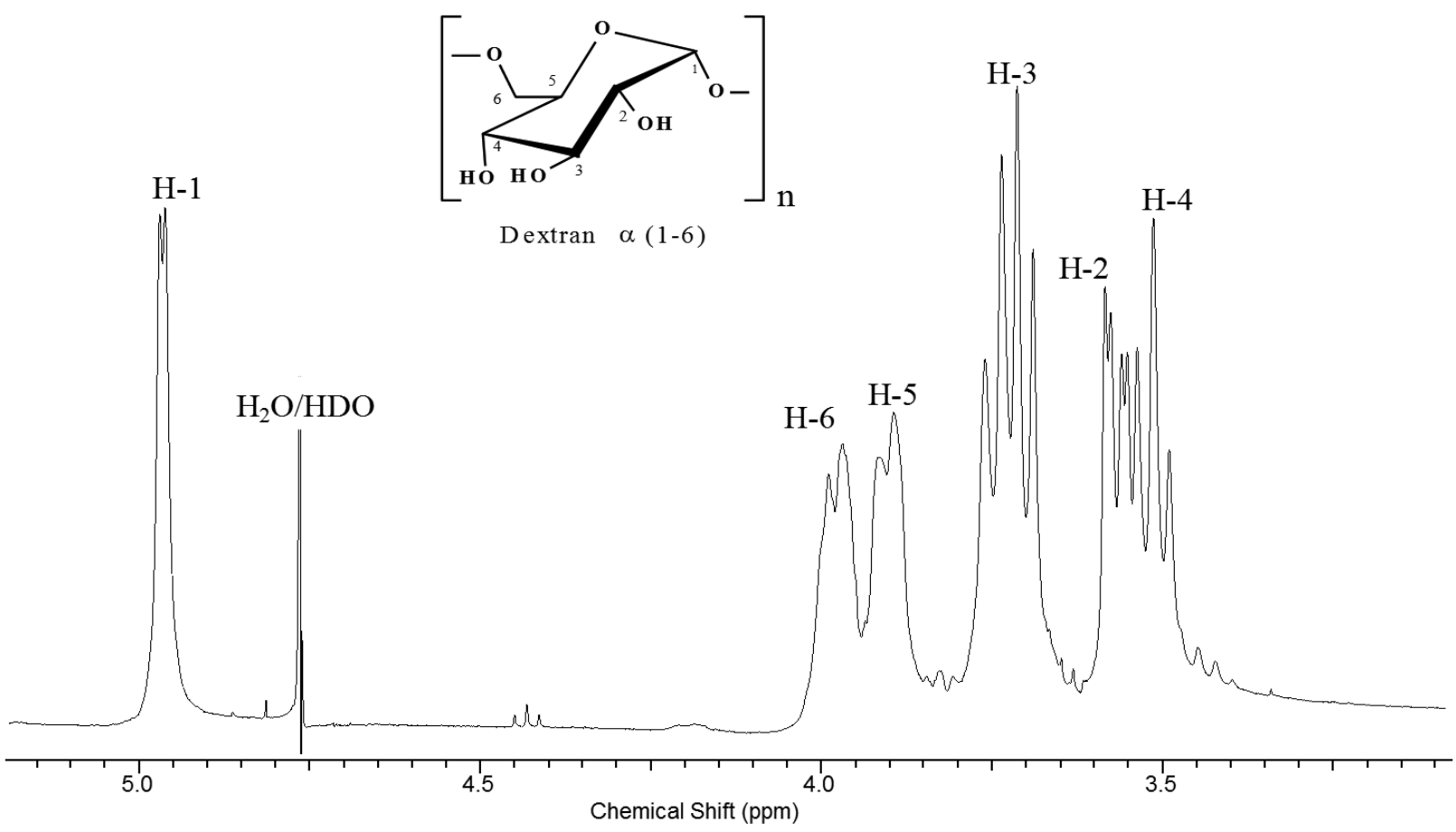

Fig. $5{ }^{1} \mathrm{H}$ NMR spectrum of EPS II produced by Leuconostoc pseudomesenteroides R2 (400 MHz, in $\left.\mathrm{D}_{2} \mathrm{O}\right)$ 


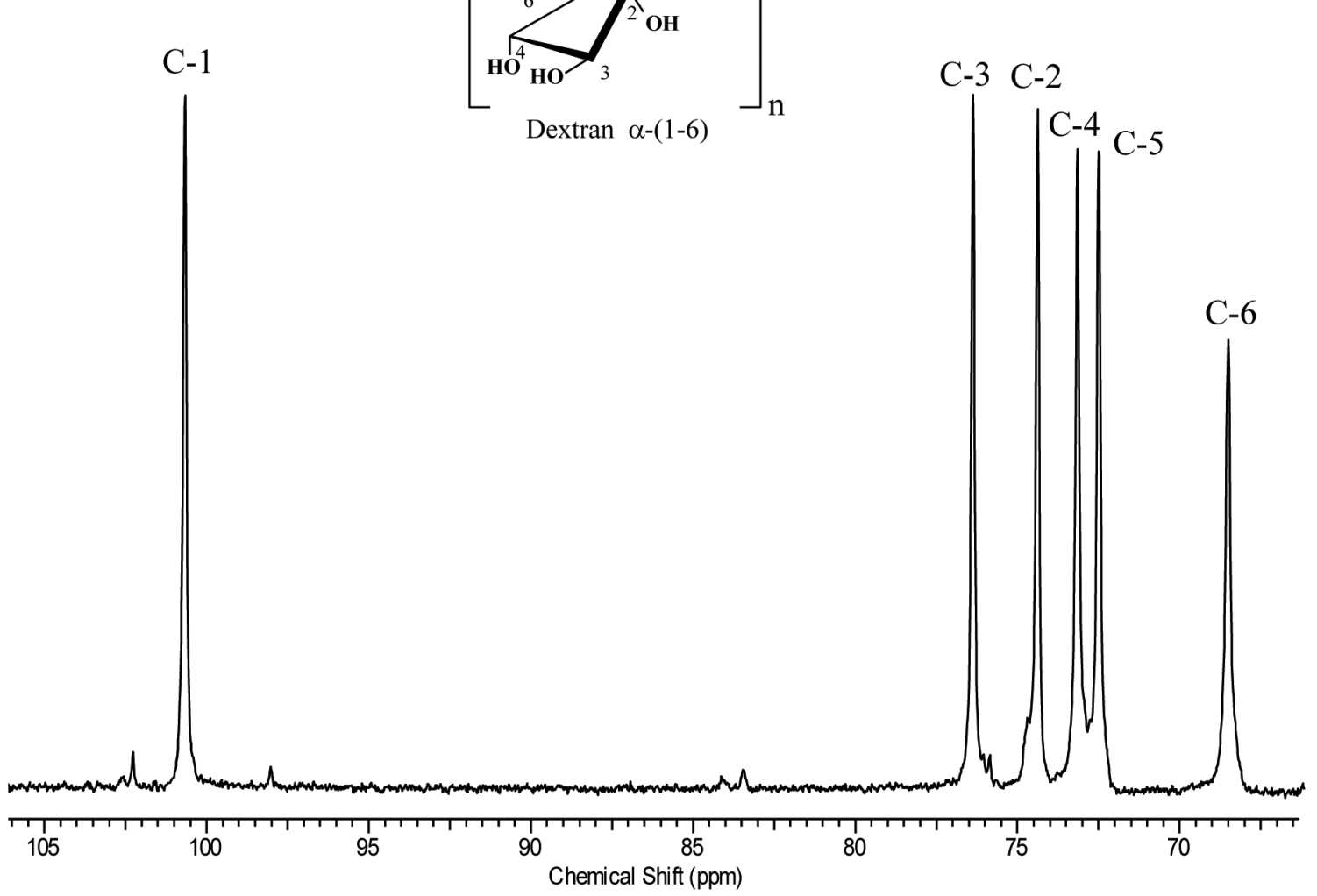

Fig. $6{ }^{13} \mathrm{C}$ NMR spectrum of EPS II produced by Leuconostoc pseudomesenteroides $\mathrm{R} 2\left(100 \mathrm{MHz}\right.$, in $\left.\mathrm{D}_{2} \mathrm{O}\right)$

All data from NMR experiments $\left({ }^{1} \mathrm{H},{ }^{13} \mathrm{C}\right.$ and DEPT-135) for the EPS I, EPS II and commercial D-glucose, as well as the published reports used to confirm the structures of the exopolysaccharides, are summarized in Table I.

The analysis of exopolysaccharides produced by the Leuconostoc pseudomesenteroides R2 strain by infrared, ${ }^{1} \mathrm{H},{ }^{13} \mathrm{C}$ and DEPT-135 NMR spectra indicated that it is a dextran, confirming the production of this polymer by the Leuconostoc pseudomesenteroides $\mathrm{R} 2$ strain.

The term dextran is employed to describe a large class of bacterial extracellular polysaccharides. The diversity within this class of biopolymers is due to the wide variety of microorganisms that produce extracellular dextran, including a wide variety of bacteria in the Lactobacillacea family and, particularly, in the genera Lactobacillus, Leuconostoc and Streptococcus (D.S. Aquino, unpublished data), when grown in media containing sucrose. Among the main species producing this polymer are the Leuconostoc dextranicum and Leuconostoc mesenteroides (Negro 1999).

The dextran produced by bacterial fermentation is called native dextran and has a high molecular weight. Obtaining dextrans with lower molecular masses for specific applications is possible through enzymatic processes (D.S. Aquino, unpublished data).

According to Alsop (1983), the precipitated dextrans are different depending on the concentration of ethanol used to form dextran with high or low molecular weight, and various 
fractions of the polymer can be formed, depending on the concentration of ethanol used. Other factors also affecting the formation of various fractions of dextran include the $\mathrm{pH}$ and the medium composition.

\section{Physical Characterization of DeXTRAns Produced By}

\section{PSEUDOMESENTEROIDES R2}

\section{Thermogravimetric analysis of dextrans extracted} from the culture of $L$. pseudomesenteroides $R 2$.

The graph presented in Figure 7 represents the results of thermogravimetric analysis of the precipitates of dextrans (EPS I and EPS II) obtained from the fermentation broth of L. pseudomesenteroides R2 and indicates that the mass loss of all precipitates was similar. At a temperature of $\pm 300^{\circ} \mathrm{C}$, about $20 \%$ mass loss was found, but with a temperature of $\pm 350^{\circ} \mathrm{C}$ this loss reaches $\pm 70 \%$, indicating decomposition of the sample. A typical thermogravimetric curve of the polymer dextran obtained from experiments carried out by Rodrigues Filho et al. (2007) exhibits similar properties to this thermogram. Through this analysis, it appears that the polymers extracted from the fermented broth of L. pseudomesenteroides R2 possess high thermal stability. According to Jeanes et al. (1974), polymers produced by the L. pseudomesenteroides type of dextran in aqueous solutions (30-10\%) are quite resistant to heat sterilization.

The density of free EPS packaging, and in particular, of EPS I, was $0.50 \mathrm{~g} / \mathrm{cm}^{3}$. EPS II displayed greater density, with a density of $0.67 \mathrm{~g} /$ $\mathrm{cm}^{3}$. In polymers, light elements generally dominate, namely $\mathrm{C}, \mathrm{H}, \mathrm{N}$ and $\mathrm{O}$. Moreover, their covalent atomic bonds are prone to the existence of dense atomic packing (Misaki et al. 1980).

Determination of viscosity: Figure 8 represents the 14:15 rheograms corresponding to EPS I and EPS II, respectively, at concentrations of $1 \%$ and $5 \%$. The behavior of the viscosity of solutions of dextran is quite variable, due to the great flexibility of the structure of this class of polymer. Solutions of dextran with concentrations of up to $5 \%(\mathrm{w} / \mathrm{v})$ exhibit Newtonian behavior. Above this concentration, solutions may demonstrate non-Newtonian behavior (D.S. Aquino, unpublished data). In solution, both exopolysaccharides presented a pseudoplastic behavior as the apparent viscosity decreased with an increasing shear rate. According to the literature,



Fig. 7 Thermogravimetric analysis of different fractions of EPS (polymer 1: compact, white; polymer 2: brown, rigid; polymer 3: transparent, flexible; polymer 4: brown, fragile; polymer 5: white, fragile; polymer 6. transparent, fragile) extracted from cultured L. pseudomesenteroides R2. 

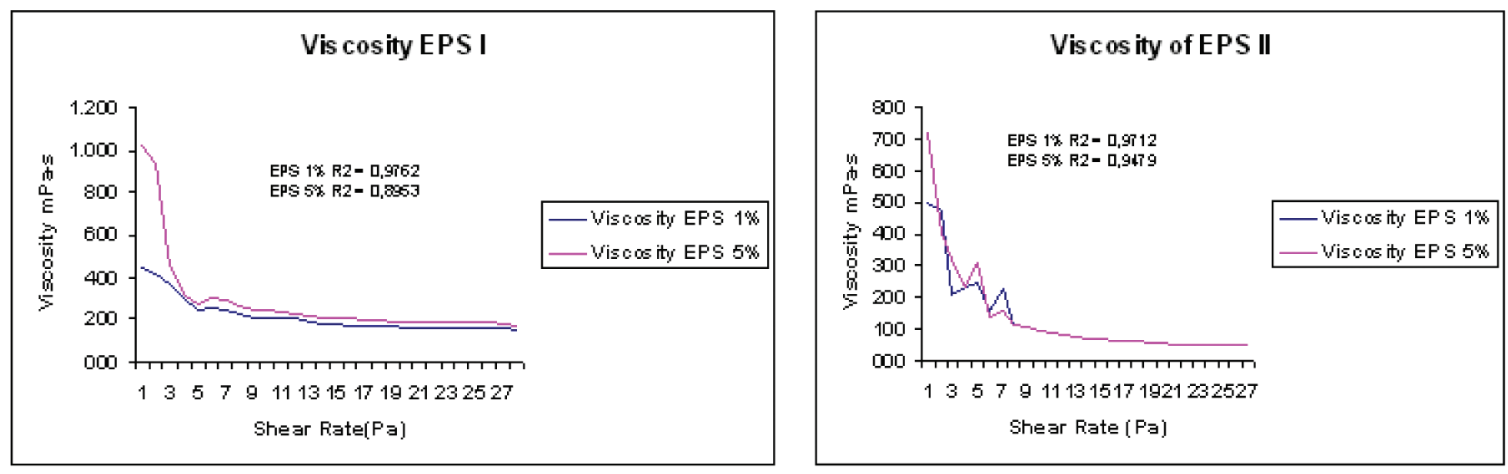

Fig. 8 Rheograms of EPS I and EPS II extracted from L. pseudomesenteroides R2

this behavior is expected in polymer solutions of microbial polysaccharides (Berwanger et al. 2007).

The dextran produced by Leuconostoc has usually no Newtonian pseudoplastic behavior. According to Sebatie et al. (1986), the pseudoplastic behavior of dextran is related to the alignment of chains in a linear fashion, followed by hydrogen bonds between molecules and the increasing in viscosity when the production of this polymer is held at low temperatures, suggesting that there is a relationship between the temperature at which dextran is synthesized and its molecular structure. Dextrans produced at low temperatures appear to be less branched and more viscous.

Table II shows the highest viscosity, at two concentrations ( $1 \%$ and $5 \%$ ), of EPS I and EPS II when compared with the same shear rate $\left(1.50 \mathrm{~s}^{-1}\right)$. Parameters that affect the viscosity of dextrans include the type of molecular structure and the concentration of polymers (Greenfield and Geronimos 1982). Specifically, viscosity will be greater with a higher molecular weight of dextran.
The results presented in Table II agree with a prior study, which observed that the viscosity of the solutions becomes higher with an increasing concentration.

Among the parameters that affect the viscosity of dextrans we have the type of molecular structure and the concentration of polymers (Greenfield and Geronimos 1982). The viscosity will be greater with a higher molecular weight of dextrans.

Solubilization of exopolysaccharides: The sample of dextran corresponding to EPS I indicated total dissolution in distilled water at $25^{\circ} \mathrm{C}$ after 1 hour, while the corresponding EPS II exhibited some solid particles over this interval of time and was completely dissolved in 2 hours and 30 minutes. The solubility of dextran can vary according to the lineage that produced it. The degree of branching affects dextran's solubility in water, with large numbers of Links 1-6 increasing the solubility of the polymer in water and indicating high stability under acidic and alkaline conditions, whereas large numbers of connections decrease this solubilization (D.S. Aquino, unpublished data).

TABLE II

Results of determining the viscosity of dextrans extracted from $L$. pseudomesenteroides $\mathrm{R} 2$

\begin{tabular}{l|cccccc}
\hline Dextrans 1\% / 5\% & $\begin{array}{c}\text { Viscosities } \\
\text { apparent }\left(\mathbf{m P a} \mathbf{s}^{-\mathbf{s}}\right)\end{array}$ & $\begin{array}{c}\text { Speed } \\
(\mathbf{r p m})\end{array}$ & \% torque & $\begin{array}{c}\text { Shear } \\
\text { stress }\end{array}$ & $\begin{array}{c}\text { Shear rate } \\
\left(\mathbf{s}^{-\mathbf{1}}\right)\end{array}$ & $\mathbf{T}^{\circ} \mathbf{C}$ \\
\hline exopolysaccharide I & $1.024 / 1.676$ & 1 & $39 / 64$ & $15 / 25$ & 1.50 & 25 \\
\hline exopolysaccharide II & $615 / 718$ & 1 & $23 / 27$ & $9 / 11$ & 1.50 & 25 \\
\hline
\end{tabular}




\section{CONCLUSION}

In this study, the Leuconostoc pseudomesenteroides R2 strain produced two types of dextran polymers, identified as $\alpha(1 \rightarrow 6)$ straight chain. Both featured the same thermal stability, but exhibited some different features, including viscosity, density of free packaging and time of dissolution in aqueous media. The use of these dextrans in industrial processes will depend on the requirements for the polymer used for each process. It is important to determine the molecular mass of dextrans synthesized by L. pseudomesenteroides $\mathrm{R} 2$ because the applicability of this type of polymer depends on whether they are of low, intermediate or high molecular weights.

\section{ACKNOWLEDGMENTS}

This work was supported by Fundação de Amparo à Pesquisa do Estado da Bahia (FAPESB); Finaciadora de Estudos e Projetos (FINEP), Coordenação de Aperfeiçoamento de Pessoal de Nível Superior (CAPES), Conselho Nacional de Desenvolvimento Científico e Tecnológico (CNPq). We also thank the Empresa Brasileira de Pesquisa Agropecuária (EMBRAPA - Meio Ambiente); Instituto de Química, Universidade Federal da Bahia (UFBA); Departamento de Química - Laboratório de Ressonância Magnética Nuclear - Universidade Federal de São Carlos (UFSCar) and the Programa de PósGraduação em Biotecnologia UEFS/FIOCRUZ.

\section{RESUMO}

O gênero Leuconostoc pertence a um grupo de bactérias lácticas normalmente isoladas de vegetais fermentados, que inclui espécies envolvidas na produção de exopolissacarídeos (EPS). Esses biopolímeros possuem potencial comercial considerável. Devido à grande variedade de aplicações industriais, de EPS, o presente estudo teve como objetivo produzir e caracterizar o nativo exopolissacarídeo cepa Leuconostoc pseudomesenteroides $\mathrm{R} 2$, que foi isolado de repolho coletado em uma região semiárida da Bahia. Utilizamos as seguintes condições para a produção de EPS: 10,7\% de sacarose, $\mathrm{pH} 8,2$, sem agitação e incubação a $28^{\circ} \mathrm{C}$ por 30 horas. $\mathrm{O}$ caldo fermentado foi tratado com etanol, gerando dois tipos de substâncias de polissacarídeos (EPS I e EPS II). A identificação do EPS I e EPS II foi realizada através das técnicas espectroscópicas de FT-IR e RMN de ${ }^{1} \mathrm{H},{ }^{13} \mathrm{C}$ e DEPT 135. As duas substâncias foram identificadas como dextrano polissacarídeos lineares $(1 \rightarrow 6)$, indicando características diferentes no que diz respeito à análise térmica e densidade de empacotamento sem viscosidade e tempo de solubilização. Ambas as dextranas são de baixa densidade, possuem alta estabilidade térmica e apresentaram comportamento característico de polímeros pseudoplásticos.

Palavras-chave: Leuconostoc pseudomesenteroides, exopolissacarideo, polimero, dextrana.

\section{REFERENCES}

ALsop RM. 1983. Industrial Production of Dextrans. ed., M. E. Bushell. New York: Elsevier, Prog Ind Microbiol, p. 1-42.

Aouada FA, Moura MR, Girotto EM, Rubira AF, Muniz EC AND CAMPESE GM. 2008. Caracterização de hidrogéis condutores constituídos por PAAm e PEDOT/PSS por meio de planejamento fatorial. Polímeros 18(2): 126-131.

ASHTAPUTRE AA AND SHAH AK. 1995. Emulsiyfing property of a viscous exopolysaccharides from Sphingomonas paucimobilis GS1., World J Microb Biot 11: 219-222.

Astolfi-Filho Z, SOUZA CA, ReIPERT ECA AND TElis VRN. 2005. Encapsulação de suco de maracujá por co-cristalização com sacarose: cinética de cristalização e propriedades físicas. Cienc Tecnol Aliment, Campinas 25(4): 795-801.

BEROVIČ M, HABIJANIČ J, ZORE I, Wraber B, HodŽAR D, BOH B AND POHLEVEN F. 2003. Submerged cultivation of Ganoderma lucidum biomass and immunostimulatory effects of fungal polysaccharides. J Biotechnol, Amsterdam 103(1): 77-86.

BERWANGER ALS, SCAMPARINI ARP, DOMINGUES NM, VANZO LT, TREICHEL H AND PADILHA FF. 2007. Produção de biopolímero sintetizado por Shingomonas capsulata a partir de meios industriais. Cienc Agrotec 31: 177-183.

Boffo EF, TaVares LA, Ferreira MMC and Ferreira AG. 2009. Classification of Brazilian vinegars according to their $1 \mathrm{H}$ NMR spectra by pattern recognition analysis. LWT - Food Sci Technol 42: 1455-1460.

BoHN JA AND BEMILLER JN. 1995. ( $1 \rightarrow 3)-\beta$-D-Glucans as biological response modifiers: a review of structure functional activity relationships. Carbohyd Polym, Barking 28(1): 3-14.

CAO W, Li XQ, LiU L, Yang TH, Li C, FAn H-T, JiA M, LU ZG AND MEI QB. 2006. Structure of antitumor polysaccharide from Angelica sinensis (Oliv) Diels. Carbohyd Polym 66: 149-159. 
CERNING J. 1995. Production of exopolysaccharides by lactic acid bacteria and dairy propionibacteria. Lait 75: 463-472.

CHI Z AND ZHAO S. 2003. Optimization of medium and cultivation conditions for pullulan production by a new strain. Enzyme Microb Tech 33: 206-211.

DILTZ S AND ZELLER SG. 2001. Location of O-acetyl groups in S-657 using the reductive cleavage method. Carbohyd Res 331: 265-270.

Dubois M, Gilles KA, HAMilton JK, Rebers PA AND SMith F. 1956. Colorimetric method for determination of sugars and related substances. Anal Chem 28(3): 350-356.

GALINDO E. 1994. Aspects of the process for xanthan production. Transactions of the Institution of Chemical Engineers 72: 227-237.

GREENFIELD PF AND GERONIMOS GL. 1982. Effect of dextrans on the viscosity of sugar solution and molasses. Int Sugar J 80: 67-72.

GuIMARÃES DP, Costa F, Rodrigues MI AND MAUGERI F. 1999. Optimization of dextran synthesis and acidic hydrolysis by surface response analysis. Braz J Chem Eng 16(2): 129-139.

JEANES BYX, HAYNES WC, WILHAM CA AND RANKISJEANES A. 1974. Characterization and Classification of Dextrans from Ninety-six Strains of Bacteria. J Amer Chem Soc, p. 5041-5052.

KoraKli M, PAVLOVIC M, GÄNZLE MG AND VoGEl FR. 2003. Exopolysaccharide and Kestose Production by Lactobacillus sanfranciscensis LTH2590. Appl Environ Microbiol 69(4): 2073-2079.

LAWS A, GU Y AND MARSHALL V. 2001. Biosynthesis, characterization, and design of bacterial exopolysaccharides from lactic acid bacteria. Biotechnol Adv 19: 597-625.

LeUng MYK, LiUb C, KoOn JCM AND Fung KP. 2006. Polysaccharide biological response modifiers. Immunol Lett, Amsterdam 105(2): 101-114.

LiU C, Lin Q, GAO Y, YE L, XING Y AND XI T. 2007. Characterization and antitumor activity of polysaccharide from Strongylo centrotus nudus eggs. Carbohyd Polym 67: 313-318.

LuCAS EF, SOARES BG AND MONTEIRO E. 2001. Caracterização de polímeros. Editora E-paper, Rio de Janeiro, 366 p.

Mesomo MC, Silva MF, Boni G, Padilha F, Mazutti M, Mossi A, Oliveira D, CANSIAN RL, Luccio MDI AND TREICHEL H. 2009. Xanthan gum produced by Xanthomonas campestris from cheese whey: production. J SCI Food Agr (ONLINE) 1: 2440-2445.

MILLER GL. 1959. Use of dinitrosalicylic reagent for determination of reducing sugar. Anal Chem 31: 426-428.

MisAKI A, TORII M, SAWAi T AND GOLDSTEIN I. 1980. Structure of the dextran of Leuconostoc meserrteroides B-1355. Carbohyd Res 84: 273-285.
NEGRO MRGOC. 1999. Caracterização da "canjica"-polímero coletado em usinas de açúcar e álcool - e estudo de fatores relacionados à sua formação a partir de gomas produzidas por Lactobacillus isolados de caldo de cana-de-açúcar. 130f. tese (Doutorado em Ciências dos Alimentos) Faculdade de Engenharia de Alimentos. Universidade Estadual de Campinas, Campinas, SP.

PACE GW. 1992. Polímeros microbianos. In: BU'LO CKJ AND KRISTIANSEN B. Biotecnología básica. Zaragoza: Acribia, p. 449-462.

RICCIARDI A AND CLEMENTI F. 2000. Exopolysaccharides from lactic acid bacteria: Structure, production and technological applcations. Italian J food Sci 1: 23-45.

Rodrigues Filho MG, Leite Neto AF, Aquino FW, Plepis AMG, Rodrigues-FilHo UP AND FranCO DW. 2007. Quantificação de dextranas em açúcares e em cachaças. Quim Nova 30(5): 1115-1118.

Rohm HaAs COMPAnY. 2002. Processo de identificação e qualificação de polímeros em um sistema aquoso, USA. Patente PI9700705-6 Data da publicação: 03/12/2002.

RuijssenaArs HJ, Stingele F AND Hartmans S. 2000. Biodegradability of food-associated extracellular polysaccharides. Current Microbiology 40: 194-199.

Sarwat F, QAdER SaU, AMAN A AND AhMEd N. 2008. Production $\&$ characterization of a unique dextran from an indigenous Leuconostoc mesenteroides CMG713. Int J Biol Sciences 4(6): 379-386.

Sebatie J, Choplin L, Paul F and Monsan P. 1986. Shearinduced structure in enzymatically-synthesized dextran solution. Rheol Acta 25: 287-285.

SEYMOUR FR. 1979. Structural analysis of dextrans containing 2-a-D-Glucosylated a-D-Glucopyranosyl residues at the branch points, by use of $13 \mathrm{C}$ nuclear magnetic ressonance spectroscopy and gas-liquid chromatography- mass spectrometry. Carbohyd Res 71: 231-250.

SHINGEL KI. 2002. Determination of structural peculiarities of dextran, pullulan and c-irradiated pullulan by Fouriertransform IR spectroscopy. Carbohyd Res 337: 1445-1451.

Silva DA, Brito ACF, De PAula RCM, Feitosa JPA AND PAULA HCB. 2003. Carbohyd Polym 54: 229-236.

SUTHERLAND I. 2002. A sticky business: microbial polysaccharides: current products and future trends. Microbiol Today [S.1.] 29: 70-71.

UZOCHUKWU S, BALOGH E, LOEFLER RT AND NGODDY PO. 2002. Structural analysis by $13 \mathrm{C}$ nuclear magnetic resonance spectroscopy of glucan extracted from natural palm wine. Food Chem 76: 287-291.

YounG SH AND JACOBS RR. 1998. Sodium hydroxide induced conformational change in schizophyllan detected by the fluorescence dye, aniline blue. Carbohyd Res, Amsterdam 310(1-2): 91-99. 